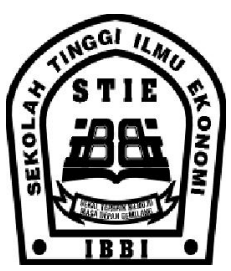

\title{
PENGARUH GOOD CORPORATE GOVERNANCE (GCG) DAN UKURAN PERUSAHAAN TERHADAP KINERJA KEUANGAN PERUSAHAAN MANUFAKTUR YANG TERDAFTAR DI BEI
}

\author{
Muhammad Fahmi ${ }^{1)}$, Dessy Rahayu ${ }^{2)}$ \\ ${ }^{1}$ STIE IBBI \\ e-mail : aqilmumtazkaffi01@gmail.com \\ ${ }^{2} \mathrm{STIE}$ IBBI \\ e-mail : dessy_rahayu_ak1_ypk@yahoo.co.id
}

\begin{abstract}
Abstrak / Abstract
Penelitian ini bertujuan untuk menguji pengaruh good corporate governance dan ukuran perusahaan terhadap kinerja keuangan perusahaan manufaktur yang terdaftar di Bursa Efek Indonesia. Indikator yang digunakan untuk menjelaskan good corporate governance dalam penelitian ini terdiri dari ukuran dewan direksi dan ukuran dewan komisaris. Untuk mengukur kinerja keuangan perusahaan digunakan Cash Flow Return On Asset (CFROA). Populasi penelitian ini adalah perusahaan manufaktur yang terdaftar di Bursa Efek Indonesia tahun 2013-2014. Sampel dipilih menggunakan metode purposive sampling dan sebanyak 86 perusahaan digunakan sebagai sampel. Hasil penelitian menunjukkan bahwa secara parsial dewan direksi dan ukuran perusahaan tidak berpengaruh terhadap kinerja keuangan perusahaan, dewan komisaris secara parsial berpengaruh terhadap kinerja keuangan perusahaan. Sedangkan secara simultan good corporate governance dan ukuran perusahaan berpengaruh terhadap kinerja keuangan pada perusahaan manufaktur yang terdaftar di Bursa Efek Indonesia periode 2013-2014.
\end{abstract}

Kata Kunci : Good Corporate Governance, Ukuran perusahaan, Cash Flow Return On Asset (CFROA)

This study aimed to examine the effect of good corporate governance and company size on the financial performance of companies listed on the Indonesia Stock Exchange. The indicators used to describe good corporate governance in this study consisted of the size of the board of directors and board size. To measure the financial performance of companies use Cash Flow Return On Asset (CFROA). The population of this research is manufacturing companies listed in Indonesia Stock Exchange 2013-2014. Samples were selected using purposive sampling method and as many as 86 companies are used as a sample. The results showed that the partial board of directors and company size does not affect the company's financial performance, the board is partially affect the company's financial performance. While simultaneously good corporate governance and firm size affect the financial performance of the companies listed in Indonesia Stock Exchange 2013-2014 period.

Keywords : Good Corporate Governance, company size, Cash Flow Return On Asset (CFROA) 


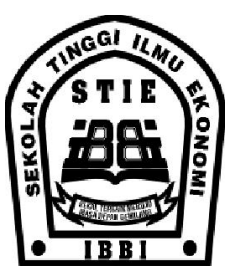

\section{PENDAhuluan}

Persaingan ekonomi yang semakin pesat sekarang ini mengakibatkan perusahaan harus lebih memperhatikan secara langsung kinerja diperusahaannya. Hal ini dilakukan agar tujuan perusahaan tercapai yaitu memaksimalkan laba dan mensejahterakan stakeholders. Dalam pencapaian kinerja keuangan yang baik, perusahaan perlu memaksimalkan kegiatan operasi seperti memaksimalkan penjualan dan mengurangi beban.

Pencapaian kinerja tersebut akan manajemen publikasikan dalam laporan keuangan. Laporan keuangan tersebut nantinya akan digunakan investor dalam membuat keputusan berinvestasi, kreditor dalam memberikan kredit pinjaman, calon investor dalam menganalisis saham serta menentukan prospek perusahaan dimasa yang akan datang.

Kinerja adalah pencapaian suatu tujuan dari kegiatan tertentu untuk mencapai tujuan perusahaan. Penilaian kinerja perusahaan diharapkan dapat membantu manajemen melihat kinerja karyawan sesuai dengan posisisinya dibandingkan dengan standar yang telah dibuat oleh perusahaan. Pengendalian kinerja yang baik didalam manajemen dapat meningkatkan profitabilitas perusahaan serta menambah kepercayaan publik terhadap perusahaan tersebut.

Namun pada kenyataannya, banyak kinerja perusahaan tidak berjalan sesuai dengan standar dan konsepnya. Hal ini diakibatkan pengendalian internal yang kurang baik, sehingga mengakibatkan terjadinya penyimpangan dan skandal-skandal keuangan yang berdampak buruk terhadap perusahaan dalam jangka panjang.

Agar hal tersebut tidak terjadi dalam perusahaan, perlu adanya tata kelola perusahaan (Good Corporate Governance) yang baik dan benar. Tata kelola perusahaan atau Good Corporate Governance sendiri merupakan sistem yang mengatur, mengelola dan mengawasi proses pengendalian perusahaan yang menciptakan nilai tambah (value added) untuk semua stakeholder dan juga sebagai alat pemantau kinerja perusahaan.

Tata kelola perusahaan (Good Corporate Governance) mulai sering terdengar $\mathrm{di}$
Indonesia pada tahun 2000 ketika Indonesia baru pulih dari krisis moneter tahun 19971998. Ada dua hal yang ditekankan dalam konsep ini, yaitu pemegang saham memiliki hak untuk memperoleh informasi dengan benar tepat pada waktunya dan kewajiban perusahaan untuk melakukan pengungkapan (disclosure) secara akurat, tepat waktu, transparan terhadap semua informasi kinerja perusahaan, kepemilikan, dan stakeholder.

Penerapan good corporate governance secara benar dan konsisten didalam perusahaan dapat meningkatan nilai perusahaan dalam jangka panjang melalui peningkatkan kinerja perusahaan. Dalam good corporate governance terdapat agency theory yang melatarbelakanginya. Selain penerapan good corporate governance yang baik, ukuran perusahaan juga berpengaruh dalam pencapaian kinerja keuangan perusahaan. Ukuran perusahaan dapat dilihat dari total asset yang dimiliki perusahaan tersebut. Semakin besar asset yang dimiliki perusahaan, maka semakin besar pula kinerja keuangan perusahaan tersebut.

Penilitian ini merupakan replikasi dari penelitian Bukhori (2012) yang melakukan penelitian untuk menguji pengaruh good corporate governance dan ukuran perusahaan terhadap kinerja perusahaan manufaktur di Indonesia. Kinerja perusahaan diukur dengan CFROA. Faktor-faktor yang diuji dalam penelitian Bukhori adalah ukuran dewan direksi dan ukuran dewan komisaris sebagai mekanisme internal corporate governance dan ukuran perusahaan.

Metode pengumpulan data yang digunakan oleh Bukhori yaitu metode random sampling terhadap perusahaan manufaktur yang terdaftar di Bursa Efek Indonesia tahun 2010. Sebanyak 160 perusahaan digunakan sebagai sampel. Metode analisis yang digunakan adalah regresi berganda. Hasil penelitian menunjukkan corporate governance tidak berpengaruh signifikan terhadap kinerja perusahaan. Ukuran perusahaan tidak berpengaruh signifikan terhadap kinerja perusahaan. Bukhori menyimpulkan bahwa mekanisme internal corporate governance dan ukuran perusahaan tidak berpengaruh terhadap kinerja perusahaan. 


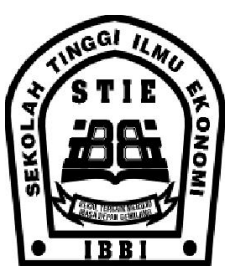

Mengingat bahwa penelitian dalam 10 tahun terakhir belum ada batasan yang jelas mengenai variabel kinerja perusahaan non keuangan, maka penelitian ini mencoba untuk meneliti kembali lebih dalam pengaruh Good Corporate Governance dan ukuran perusahaan terhadap kinerja keuangan perusahaan pada Perusahaan Manufaktur yang diukur dengan Cash Flow Return on Asset (CFROA).

Dalam penelitian ini Good Corporate Governance di proksi dengan Ukuran Dewan Direksi dan Ukuran dewan Komisaris yang merupakan struktur pengendalian internal perusahaan. Dengan melihat jumlah anggota Dewan Direksi dan Dewan Komisaris, kita dapat mengetahui kinerja keuangan perusahaan. Pengukuran kinerja keuangan perusahaan dalam penelitian ini menggunakan Cash Flow Return on Asset (CFROA). CFROA merupakan salah satu rasio keuangan lain yang digunakan dalam pengukuran kinerja keuangan perusahaan yang menunjukkan kemampuan aktiva perusahaan untuk menghasilkan laba dan tidak terikat dengan harga saham. (Cornett et al 2006:1776).

Metode penelitian dalam penelitian ini adalah statistik deskriptif dengan data kuantitatif yang berbentuk angka-angka. Populasi dalam penelitian ini adalah perusahaan manufaktur yang terdaftar di Bursa Efek Indonesia periode 2013-2014 dengan pemilihan sampel menggunakan purposive sampling. Metode analasis yang digunakan dalam penelitian ini adalah regresi linier berganda.

Berdasarkan latar belakang dan uraian ini, maka penelitian ini mengambil judul "Pengaruh Good Corporate Governance (GCG) Dan Ukuran Perusahaan Terhadap Kinerja Keuangan Perusahaan Manufaktur Yang Terdaftar Di Bursa Efek Indonesia Tahun 2013-2014".

\section{Identifikasi Masalah}

Berikut ini merupakan beberapa masalah yang dapat penulis identifikasi adalah:

1. Terdapat indikasi bahwa kinerja keuangan perusahaan dipengaruhi oleh Good Corporate Governance (yang diproksi sebagai ukuran dewan direksi dan ukuran dewan komisaris) dan ukuran perusahaan.

2. Terdapat identifikasi bahwa kinerja keuangan perusahaan dipengaruhi oleh jumlah dewan direksi dalam pengambilan keputusan dan menentukan arah kebijakan dan strategi baik jangka pendek maupun jangka panjang perusahaan.

3. Terdapat identifikasi bahwa kinerja keuangan perusahaan dipengaruhi oleh jumlah dewan komisaris dalam melakukan pengawasan tehadap kelengkapan dan kualitas informasi laporan kinerja dewan direksi dan ketepatan dalam pengambilan keputusan didalam perusahaan.

4. Terdapat identifikasi bahwa kinerja keuangan perusahaan dipengaruhi oleh ukuran perusahaan dalam menunjang perkembangan perusahaan.

\section{Batasan Masalah}

Agar masalah yang diteliti dalam penelitian ini terarah dan jelas, maka peneliti memberikan batasan masalah sebagai berikut:

1. Penelitian ini hanya menggunakan dua variabel bebas yaitu Good Corporate Governance dan ukuran perusahaan

2. Perusahaan yang dipilih sebagai sampel adalah perusahaan manufaktur yang terdaftar di BEI dan menerbitkan laporan keuangan tahunan yang telah diaudit selama periode pengamatan, yaitu tahun 2013 sampai dengan 2014.

\section{Rumusan Masalah}

Berdasarkan latar belakang masalah diatas, maka rumusan permasalahan dalam penelitian ini adalah:

1. Apakah Good Gorporate Governance yang diproksi sebagai ukuran dewan direksi dan ukuran dewan komisaris berpengaruh terhadap kinerja keuangan pada perusahaan Manufaktur yang terdaftar di BEI tahun 2013-2014? 


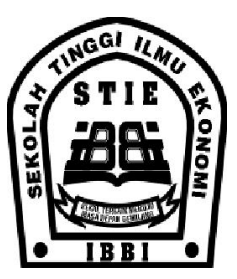

2. Apakah ukuran perusahaan berpengaruh terhadap kinerja keuangan pada perusahaan Manufaktur yang terdaftar di BEI tahun 2013-2014)?

3. Apakah variabel Good Corporate Governance yang diproksi sebagai ukuran dewan direksi dan ukuran dewan komisaris dan variabel ukuran perusahaan berpengaruh terhadap kinerja keuangan pada perusahaan Manufaktur yang terdaftar di BEI tahun 2013-2014?

\section{Tujuan Penelitian}

Berdasarkan perumusan masalah tersebut, penelitian ini dilakukan dengan tujuan sebagai berikut:

1. Menguji dan menganalisis pengaruh Good Corporate Governance yang diproksi sebagai ukuran dewan direksi dan ukuran dewan komisaris terhadap kinerja keuangan pada perusahaan Manufaktur yang terdaftar di BEI tahun 2013-2014.

2. Menguji dan menganalisis pengaruh ukuran perusahaan terhadap kinerja keuangan pada perusahaan Manufaktur yang terdaftar di BEI tahun 2013-2014.

3. Menguji dan menganalisis variabel Good Corporate Governance yang diproksi sebagai ukuran dewan direksi dan ukuran dewan komisaris dan variabel ukuran perusahaan berpengaruh terhadap kinerja keuangan pada perusahaan Manufaktur yang terdaftar di BEI tahun 2013-2014.

\section{Kegunaan Penelitian}

Penelitian ini diharapkan dapat memberikan manfaat bagi pihak-pihak yang berkepentingan :

1. Bagi Peneliti

Diharapkan hasil penelitian membuktikan secara empiris Good Corporate Governance dan ukuran perusahaan berpengaruh secara parsial dan simultan terhadap kinerja keuangan yang diukur dengan Cash Flow Return on Asset (CFROA).

2. Bagi manajemen perusahaan

Hasil penelitian dapat digunakan oleh perusahaan manufaktur dalam menilai kinerja keuangan serta melihat efektifitas dan efisiensi penggunaan asset dalam menghasilkan pendapatan.

3. Bagi akademik

Sebagai dokumen akademik yang berguna dan bahan referensi bagi peneliti selanjutnya pada perpustakaan STIE IBBI.

\section{TINJAUAN LITERATUR}

\section{Teori Keagenan (Agency Theory)}

Teori keagenan merupakan basis teori yang mendasari praktik bisnis perusahaan yang dipakai selama ini. Teori agensi menyatakan adanya hubungan kontraktual antara pemilik modal (principal) dengan manajer (agent). Inti dari hubungan keagenan ini adalah terdapat pemisahan antara kepemilikan dan pengelolaan perusahaan.

Tujuan utama teori keagenan (agency theory) adalah untuk menjelaskan bagaimana pihak-pihak yang melakukan hubungan kontrak dapat mendesain kontrak yang tujuannya untuk meminimalisir biaya (cost) sebagai dampak adanya informasi yang tidak simetris dan kondisi yang mengalami ketidakpastian.

Teori keagenan ini dikembangkan oleh Michael C. Jensen dan William H. Meckling tahun 1976. Dalam teori keagenan (agency theory), hubungan agensi muncul ketika pemilik modal (principal) mempekerjakan orang lain (agent) untuk memberikan suatu jasa dan kemudian melimpahkan tanggung jawab wewenang pengambilan keputusan operasional perusahaannya kepada agent tersebut sesuai dengan kontrak kerja yang telah disepakati.

Menurut Jensen dan Meckling (1976), terdapat dua macam asimetri informasi yaitu:

1. Adverse Selection, yaitu suatu keadaan dimana principal tidak dapat mengetahui apakah suatu keputusan yang diambil oleh agent benar-benar didasarkan atas 


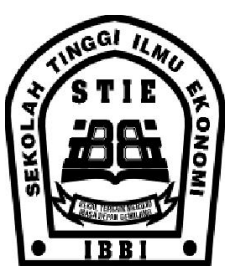

informasi yang telah diperolehnya atau terjadi sebagai sebuah kelalaian tugas.

2. Moral Hazard, yaitu permasalahan yang timbul jika agent tidak dapat melaksanakan hal-hal yang telah disepakati bersama dalam kontrak kerja.

\section{Pengertian dan Konsep Dasar Kinerja}

Performance atau kinerja merupakan suatu pola tindakan yang dilaksanakan untuk mencapai tujuan yang diukur dengan mendasarkan pada suatu perbandingan dengan berbagai standar. Kinerja adalah pencapaian suatu tujuan dari suatu kegiatan atau pekerjaan tertentu untuk mencapai tujuan perusahaan yang diukur dengan standar (Gozali., 2012:40).

Menurut Ikatan Akuntansi Indonesia (1996), kinerja perusahaan dapat diukur dengan menganalisa dan mengevaluasi laporan keuangan. Informasi yang digunakan dalam mengukur kinerja keuangan adalah informasi keuangan (financial information), yaitu informasi akuntansi manajemen dan informasi akuntansi keuangan.

Kinerja keuangan perusahaan adalah hasil banyak keputusan individual yang dibuat secara terus menerus oleh manajemen (Trinanda dan Mukodim., 2010:3). Oleh karena itu untuk menilai kinerja perusahaan perlu melibatkan analisis dampak keuangan kumulatif dan ekonomi dari keputusan dan mempertimbangkannya dengan menggunakan ukuran komparatif. Kinerja keuangan merupakan salah satu faktor yang menunjukkan efektifitas dan efisien suatu organisasi dalam rangka mencapai tujuannya.

\section{Evaluasi Kinerja}

Evaluasi adalah suatu proses untuk menyediakan informasi tentang sejauh mana suatu kegiatan tertentu telah dicapai, bagaimana perbedaan pencapaian itu dengan suatu standar tertentu untuk mengetahui apakah ada selisih diantara keduanya, serta bagaimana manfaat yang telah dikerjakan itu bila dibandingkan dengan harapan-harapan yang ingin diperoleh (Umar., 2003:36).

Evaluasi kinerja merupakan suatu bentuk refleksi kewajiban dan tanggung jawab untuk melaporkan kinerja, aktivitas dan sumber daya yang telah dipakai, dicapai dan telah dilakukan.

Evaluasi kinerja bisa disebut sebagai penilaian prestasi kerja yang dalam hal ini merupakan bagian dari fungsi manajemen yang penting yaitu evaluasi dan pengawasan. Evaluasi kinerja sekarang ini merupakan keharusan, dan sudah terus menerus dilakukan, terutama dengan melibatkan para pelanggan.

Evaluasi kinerja atau yang disebut juga sebagai penilaian kinerja yang dilakukan dalam suatu perusahaan, mempunyai tujuan sebagai berikut:

1. Untuk memperoleh pendapatan wajar atas penyertaan dalam suatu perusahaan atau mewujudkan bahwa perusahaan bernilai lebih dari apa yang ada didalam neraca.

2. Untuk keperluan merger dan akuisisi yaitu untuk mengetahui berapa nilai perusahaan dan nilai ekuitas dari masing-masing perusahaan.

3. Untuk kepentingan usaha, yang bertujuan untuk mengetahui apakah nilai usaha lebih besar dari pada nilai likuiditasnya.

4. Memperoleh pembelanjaan penetapan besarnya pinjaman atau tambahan modal.

Karena penilaian kinerja keuangan perusahaan berdasarkan laporan keuangan, maka penelitian ini menggunakan rasio keuangan yaitu Cash Flow Return On Asset (CFROA). CFROA merupakan salah satu rasio keuangan lain yang digunakan dalam pengukuran kinerja perusahaan yang menunjukkan kemampuan aktiva perusahaan untuk menghasilkan laba operasi. CFROA lebih memfokuskan pada pengukuran kinerja perusahaan saat ini dan CFROA tidak terikat dengan harga saham (Cornett et al., 2006:1776).

Penggunaan analisis rasio bertujuan untuk menentukan tingkat kinerja suatu perusahaan. Perhitungan rasio tersebut akan digunakan untuk menilai posisi kinerja suatu perusahaan, memberikan gambaran yang jelas tentang baik atau tidaknya kegiatan operasional suatu perusahaan, yang dapat dilihat dari posisi keuangannya dalam neraca dan laba-rugi yang 


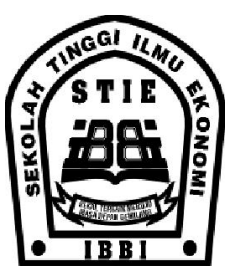

terdapat dalam laporan keuangan perusahaan tersebut.

\section{Good Corporate Governance}

Komite Nasional Kebijakan Governance (2006:3) mendefinisikan good corporate governance sebagai suatu proses dan struktur yang digunakan oleh organ perusahaan guna memberikan nilai tambah pada perusahaan secara berkesinambungan dalam jangka panjang bagi pemegang saham, dengan tetap memperhatikan kepentingan stakeholder lainnya, berlandaskan peraturan perundangan dan norma yang berlaku.

Menurut Komite Nasional Kebijakan Governance (2006:5), terdapat lima prinsip dasar yang dapat diterapkan pada setiap aspek bisnis dan disemua jajaran perusahaan dalam good corporate governance. Adapun kelima prinsip tersebut adalah sebagai berikut :

1. Transparancy (Transparansi)

2. Accountability (akuntabilitas)

3. Responsibility (pertanggungjawaban)

4. Independency (kemandirian)

5. Fairness (kesetaraan dan kewajaran)

Menurut Forum Corporate Governance in Indonesia (FCGI) ada beberapa manfaat yang dapat kita ambil dari penerapan good corporate governance yang baik, antara lain:

1. Meningkatkan kinerja perusahaan melalui terciptanya proses pengambilan keputusan yang lebih baik, meningkatkan efisiensi operasional perusahaan serta lebih meningkatkan pelayanan kepada stakeholder.

2. Mempermudah diperolehnya dana pembiayaan yang lebih murah yang pada akhirnya akan meningkatkan corporate value.

3. Mengembalikan kepercayaan investor untuk kembali menanamkan modalnya di Indonesia.

4. Pemegang saham akan merasa puas dengan kinerja perusahaan karena sekaligus akan meningkatkan Shareholders's value dan deviden.
Pelaksanaan corporate governance yang baik merupakan langkah penting dalam membangun kepercayaan pasar (market convidence) dan mendorong arus investasi internasional yang lebih stabil dan bersifat jangka panjang. Menurut IICG (2000), keuntungan yang bisa diambil oleh perusahaan apabila menerapkan konsep good corporate governance adalah :

1. Meminimalkan agency cost

2. Mengurangi biaya modal (cost of capital)

3. Memaksimalkan nilai saham perusahaan

4. Mendorong Dewan Komisaris, anggota Direksi, pemegang saham dalam membuat keputusan dan menjalankan tindakan dilandasi moral yang tinggi dan kepatuhan terhadap perundang-undangan yang berlaku.

5. Menjaga Going Concern perusahaan.

Struktur good corporate governance terbentuk dari dua mekanisme berbeda yang membentuknya. Mekanisme ini merupakan suatu aturan main, prosedur dan hubungan yang jelas antara pihak yang mengambil keputusan dengan pihak yang melakukan kontrol terhadap keputusan tersebut. Kedua mekanisme tersebut yaitu:

1. Struktur mekanisme pengendalian internal perusahaan

Pihak- pihak yang terlibat dalam mekanisme internal adalah agent dan principal yang terdiri komposisi board of directors (Dewan Direksi) dan executive manajer didalam perusahaan.

2. Struktur mekanisme pengendalian eksternal perusahaan

Struktur mekanisme pengendalian eksternal terdiri dari stakeholder yang berkepentingan dan berhubungan dengan perusahaan antara lain Pasar Modal, Pasar Uang, Auditor, Paralegal dan regulator.

Penelitian ini berfokus pada struktur pengendalian internal perusahaan yang terdiri dari dewan komisaris dan dewan direksi.

\section{Dewan Komisaris}

Forum for Corporate Governance Indonesia (FCGI) mendefinisikan Dewan Komisaris sebagai inti corporate governance (tata kelola perusahaan) yang 


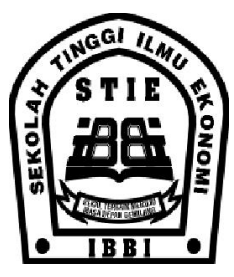

ditugaskan untuk menjamin pelaksanaan strategi perusahaan, mengawasi manajemen dalam mengelola perusahaan serta mewajibkan terlaksananya akuntabilitas.

Menurut Undang-Undang Perseroan Terbatas Nomor 40 tahun 2007, pada pasal 108 ayat (5) dijelaskan bahwa bagi perusahaan berbentuk perseroan terbatas, maka wajib memiliki paling sedikitnya 2 (dua) anggota Dewan Komisaris. Oleh karena itu, jumlah anggota Dewan Komisaris disesuaikan dengan kompleksitas perusahaan dengan tetap memperhatikan efektivitas dalam pengambilan keputusan.

\section{Dewan Direksi}

Dewan Direksi merupakan pihak dalam suatu entitas perusahaan yang bertugas melakukan melaksanakan operasi dan kepengurusan perusahaan. Anggota Dewan Direksi diangkat oleh RUPS.

Menurut Undang-Undang Perseroan Terbatas, yang dapat diangkat menjadi anggota Dewan Direksi adalah orang perseorangan yang mampu melaksanakan perbuatan hukum dan tidak pernah dinyatakan pailit atau menjadi anggota Dewan Direksi atau Komisaris yang dinyatakan bersalah menyebabkan perusahaan dinyatakan pailit, atau orang yang pernah dihukum karena melakukan tindak pidana yang merugikan keuangan negara dalam waktu lima tahun sebelum pengangkatan.

Dewan Direksi bertanggung jawab penuh atas segala bentuk operasional dan kepengurusan perusahaan dalam rangka melaksanakan kepentingan-kepentingan dalam pencapaian tujuan perusahaan. Dewan Direksi juga bertanggung jawab terhadap urusan perusahaan dengan pihak-pihak eksternal seperti pemasok, konsumen, regulator dan pihak legal.

Dengan peran yang begitu besar dalam pengelolaan perusahaan ini, direksi pada dasarnya memiliki hak pengendalian yang signifikan dalam pengelolaan sumber daya perusahaan dan dana dari investor.

\section{Ukuran Perusahaan}

Ukuran perusahaan merupakan salah satu variabel penting dalam pengelolaan perusahaan. Ukuran perusahaan mencerminkan seberapa besar total asset yang dimiliki dan dikelola perusahaan (Sujianto, 2001 dalam Bukhori, 2012:34).

Total asset yang dimiliki perusahaan menggambarkan permodalan, serta hak dan kewajiban yang dimilikinya. Semakin besar ukuran perusahaan, dapat dipastikan semakin besar juga dana yang dikelola dan semakin kompleks pula pengelolaannya.

Perusahaan besar cenderung mendapat perhatian lebih dari masyarakat luas. Dengan demikian, biasanya perusahaan besar memiliki kecenderungan untuk selalu menjaga stabilitas dan kondisi perusahaan. Untuk menjaga stabilitas dan kondisi ini, perusahaan tentu saja akan berusaha mempertahankan dan terus meningkatkan kinerjanya.

\section{KERANGKA BERFIKIR}

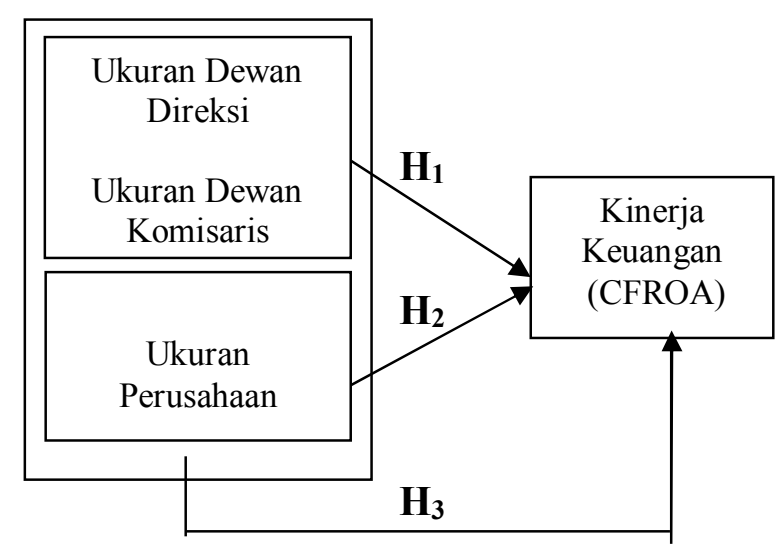

Gambar 1.1 Kerangka Konseptual

Kerangka konseptual di atas menjelaskan variabel good corporate governance yang diproksikan dengan ukuran dewan direksi dan ukuran dewan komisaris dan variabel ukuran perusahaan berpengaruh terhadap kinerja keuangan yang ada dalam suatu perusahaana. Kinerja keuanga perusahaan diukur dengan ukuran keuangan menggunakan CFROA.

Dewan direksi memiliki peranan yang sangat penting dalam suatu perusahaan. Jumlah dewan direksi sangat berpengaruh terhadap kecepatan pengambilan keputusan untuk meningkatkan kinerja keuangan 


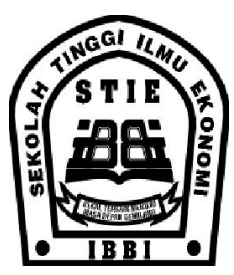

perusahaan. Dewan direksi memiliki tugas untuk menentukan arah kebijakan dan strategi sumber daya yang dimiliki oleh perusahaan, baik untuk jangka pendek maupun untuk jangka panjang.

Dewan komisaris bertugas melakukan pengawasan terhadap kelengkapan dan kualitas informasi laporan atas kinerja dewan direksi. Ukuran dewan komisaris juga berpengaruh terhadap kinerja keuangan perusahaan. Semakin banyak jumlah dewan komisaris didalam perusahaan, menyebabkan pengambilan buruknya kinerja perusahaaan. Hal ini terjadi karena kesulitan komunikasi dan koordinasi antar anggota dewan komisaris.

Ukuran perusahaan sangat berpengaruh terhadap perkembangan perusahaan. Semakin besar perusahaan maka semakin besar pua total asset yang dimilikinya dalam menunjang kinerja keuangan perusahaan. Dalam penelitian ini ukuran perusahaan diukur dengan melihat seberapa besar asset yang dimiliki oleh perusahaan. Perusahaan dengan jumlah aset lebih besar biasanya memiliki perhatian lebih dan diharapkan perusahaan lebih berhati-hati dalam melakukan pelaporan keuangannya.

\section{METODOLOGI PENELITIAN}

Metode yang digunakan dalam penelitian ini adalah statistik deskriptif. Dalam penelitian ini variabel dependen yang digunakan adalah kinerja keuangan. Kinerja keuangan dalam penelitian ini diukur dari laporan keuangan dengan menggunakan rasio keuangan yaitu Cash Flow Return On Asset (CFROA).

CFROA dihitung dari laba sebelum bunga dan pajak ditambah depresiasi dibagi dengan total aktiva. Pengukuran CFROA dilakukan dengan menggunakan rumus sebagai berikut :

$$
C F R O A=\frac{E B I T+D E P}{A s s e t}
$$

Variabel independen dalam penelitian ini yaitu good corporate governance (yang diproksi dengan ukuran dewan direksi dan ukuran dewan komisaris) dan ukuran perusahaan yang diukur dengan menggunakan jumlah total asset yang ada didalam perusahaan.

Data yang digunakan dalam penelitian ini adalah data kuantitatif. Populasi pada penelitian ini adalah perusahaan manufaktur yang terdaftar di Bursa Efek Indonesia tahun 2013-2014 yang berjumlah 143 perusahaan. Metode pemilihan sampel menggunakan purposive sampling dengan beberapa kriteria, dan sebanyak 86 perusahaan terpilih menjadi sampel.

Teknik analisis data yang digunakan dalam penelitian ini yaitu regresi linier berganda (multiple linier regression) dengan persamaan regresi sebagai berikut:

$$
\mathbf{Y}=\mathbf{B}_{\mathbf{0}}+\mathbf{B}_{1} \mathbf{X}_{1}+\mathbf{B}_{2} \mathbf{X}_{2}+\mathbf{B}_{3} \mathbf{X}_{3}+\mathbf{e}
$$

Dimana :

$$
\begin{array}{ll}
\mathrm{Y} & : \begin{array}{l}
\text { Kinerja Keuangan Perusahaan } \\
\text { (Cash Flow Return on Asset })
\end{array} \\
\mathrm{B}_{0} & \begin{array}{l}
\text { :Konstanta } \\
\mathrm{B}_{1}, \mathrm{~B}_{2}, \mathrm{~B}_{3}
\end{array} \\
\mathrm{X}_{1} & \text { : Koefisisen Regresi } \\
\mathrm{X}_{2} & \text { : Dewan Direksi } \\
\mathrm{X}_{3} & \text { : Dewan Komisaris } \\
\mathrm{e} & \text { : Error }
\end{array}
$$

Analisis data dilakukan setelah memenuhi asumsi klasik berupa uji normalitas, uji multikolinearitas, uji heteroskedastisitas dan uji autokorelasi. Penarikan kesimpulan atas hipotesis dilakukan dengan cara uji t, uji $\mathrm{F}$ pada level signifikan $5 \%$ dan uji koefisien determinasi $\left(\mathrm{R}^{2}\right)$. Keseluruhan tabulasi dan pengolahan data menggunaka SPSS versi 18 .

\section{HASIL PENELITIAN Hasil Statistik Deskriptif}

Analisis statistik deskriptif ini bertujuan untuk mencari kecendrungan terpusat (central tendency) seperti, nilai minimum, nilai maksimum, nilai rata-rata (mean), dan standar deviasi dari variabel-variabel independen dan variabel dependen. Dari hasil pengujian dapat disimpulkan sebagai berikut :

1. Varibel Dewan Direksi $\left(\mathrm{X}_{1}\right)$ memiliki nilai minimum sebesar 0,69 pada tahun 20132014 yaitu PT Ever Shine Textile Industry Tbk, PT Indorama Synthethics Tbk, PT Pelangi Indah Canindo Tbk, PT Star Petrochem Tbk, dan PT Nusantara Inti Corpora Tbk. Nilai maksimum sebesar 2,64 yaitu PT Mandom Indonesia Tbk pada tahun 2014. Nilai rata-rata (mean) sebesar 1,5740 dan standar deviasi sebesar 0,45661 


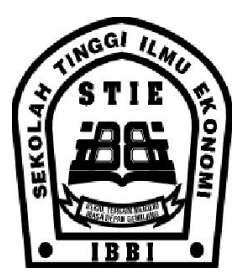

yang menunjukkan standar deviasi yang relatif kecil, karena nilai standar deviasi lebih kecil dari nilai rata-rata (mean).

2. Variabel Dewan Komisaris $\left(\mathrm{X}_{2}\right)$ yang memiliki nilai minimum sebesar 0,69 pada tahun 2013 yaitu PT Betonjaya Manunggal Tbk, PT Ekadharma International Tbk, PT Ever Shine Textile Industry Tbk, PT Pelangi Indah Canindo Tbk, PT Star Petrochem Tbk, PT Siantar Top Tbk, dan PT Nusantara Inti Corpora Tbk. Sedangkan untuk tahun 2014 yaitu yaitu PT Betonjaya Manunggal Tbk, PT Ekadharma International Tbk, PT Ever Shine Textile Industry Tbk, PT Taisho Pharmaceutical Indonesia Tbk, PT Star Petrochem Tbk, PT Siantar Top Tbk, dan PT Nusantara Inti Corpora Tbk. Nilai maksimum sebesar 2,56 yaitu PT Indo Kordsa Tbk. Nilai ratarata (mean) sebesar 1,3857 dan standar deviasi sebesar 0,42797 yang menunjukkan standar deviasi yang relatif kecil, karena nilai standar deviasi lebih kecil dari nilai rata-rata (mean).

3. Variabel Ukuran Perusahaan $\left(\mathrm{X}_{3}\right)$ memiliki nilai minimum sebesar 25,30 yaitu PT Kedaung Indah Can Tbk pada tahun 2014, sedangkan untuk tahun 2013 tidak ada. Nilai maksimum sebesar 33,09 dimiliki oleh PT Asia Internasional Tbk pada tahun 2014 saja. Nilai rata-rata (mean) sebesar 28,3600 dan nilai standar deviasi sebesar 1,63274 ini menunjukkan standar deviasi yang relatif kecil, karena nilai standar deviasi lebih kecil dari nilai rata-rata (mean).

4. Variabel Kinerja Keuangan (Y) memiliki nilai minimum sebesar -2,49 yaitu PT Steel Pipe Industry of Indonesia Tbk pada tahun 2014, sedangkan untuk tahun 2013 tidak ada. Nilai maksimum sebesar 0,18 dimiliki oleh PT Multi Bintang Indonesia Tbk pada tahun 2014 saja. Nilai rata-rata (mean) sebesar $-0,9726$ dan nilai standar deviasi sebesar 0,51601 ini menunjukkan standar deviasi yang relatif besar, karena nilai standar deviasi lebih besar dari nilai ratarata (mean).

\section{Hasil Asumsi Klasik}

1. Hasil Uji Normalitas

Dari hasil pengujian diperoleh besarnya nilai signifikan adalah 0,427 lebih besar dari nilai taraf signifikan yaitu 0,05 . Nilai tersebut menunjukkan bahwa data berdistribusi normal dan mendukung uji normalitas, sehingga dapat dilanjutkan dengan uji asumsi klasik lainnya.

\section{Hasil Uji Multikolinearitas}

Berdasarkan hasil pengujian data nilai Tolerance lebih besar dari 0,10 (nilai tolerance berkisar antara 0,468 sampai 0,479). Begitu juga dengan nilai VIF, lebih kecil 10 (nilai VIF berkisar antara 2,090 sampai 2,138). Jadi dapat disimpulkan bahwa model regresi dalam penelitian ini tidak terjadi multikolinearitas.

\section{Hasil Uji Autokorelasi}

Hasil pengujian autokorelasi dengan nilai durbin watson sebesar 1,979. Dengan menggunakan bantuan tabel durbin watson diperoleh nilai dL (nilai batas bawah) sebesar 1,7152 dan dU (nilai batas atas) sebesar 1,7861 .

$$
\begin{array}{ll}
\mathrm{dL} & =1,7152 \\
\mathrm{dU} & =1,7861 \\
\mathrm{~d} & =1,983 \\
4-\mathrm{dU} & =4-1,7861=2,2139 \\
4-\mathrm{dL} & =4-1,7152=2,2848
\end{array}
$$

Penjelasan diatas dapat disimpulkan bahwa nilai durbin watson berada diantara $\mathrm{dU}$ dan 4-dU, yaitu $1,7861<1,983<2,2139$ yang berarti bahwa tidak ada autokorelasi positif maupun negatif dalam model regresi ini.

\section{Hasil Uji Analisis Regresi Linier Berganda}

Persamaan regresi linier berganda yaitu:

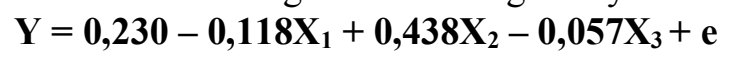
Berdasarkan persamaan regresi diatas, dapat dijelaskan sebagai berikut:

1. Nilai konstanta (a) sebesar 0,230

Nilai konstanta tersebut menunjukkan bahwa adanya pengaruh dewan direksi, dewan komisaris, dan ukuran perusahaan sehingga terjadi kenaikan sebesar 0,230 apabila varibel independen dianggap nol.

2. Nilai dewan direksi $\left(\mathrm{X}_{1}\right)$ sebesar $-0,118$

Nilai tersebut menunjukkan adanya hubungan negatif antara dewan direksi 


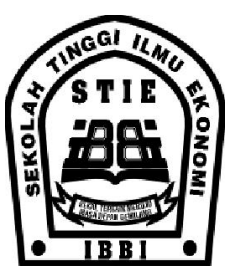

dengan kinerja keuangan yang artinya jika dewan direksi naik sebesar satu dan variabel lain dianggap nol, maka kinerja keuangan akan mengalami penurunan sebesar 0,118 .

3. Nilai dewan komisaris $\left(\mathrm{X}_{2}\right)$ sebesar 0,438

Nilai tersebut menunjukkan adanya hubungan positif antara dewan komisaris dengan kinerja keuangan yang artinya jika dewan komisaris naik sebesar satu dan variabel lain dianggap nol, maka kinerja keuangan akan mengalami kenaikan sebesar 0,438 yang akan meningkatkan kualitas perusahaan.

4. Nilai Ukuran Perusahaan $\left(\mathrm{X}_{3}\right)$ sebesar 0,057

Nilai tersebut menunjukkan adanya hubungan negatif antara ukuran perusahaan dengan kinerja keuangan yang artinya jika ukuran perusahaan naik sebesar satu dan variabel lain dianggap nol, maka kinerja keuangan akan mengalami penurunan sebesar 0,057 yang akan menurunkan kualitas perusahaan.

\section{Hasil Uji Signifikan Parsial (Uji t)}

Berdasarkan hasil pengujian statistik $t$ dapat dijelaskan pengaruh variabel independen terhadap variabel dependen secara parsial sebagai berikut:

1. Berdasarkan tabel 1.5 variabel dewan direksi memiliki nilai $t_{\text {hitung }}$ sebesar $-0,960$, dengan menggunakan uji $\mathrm{t}$ diperoleh nilai $t_{\text {tabel }}$ sebesar 1.653 (dapat dilihat pada lampiran 13). Hal ini menunjukkan bahwa nilai $t_{\text {hitung }}$ lebih kecil dari nilai $t_{\text {tabel }}$ sehingga hipotesis ditolak karena tidak ada pengaruh yang signifikan antara dewan direksi terhadap kinerja keuangan perusahaan.

2. Berbeda dengan variabel dewan direksi, variabel dewan komisaris memiliki nilai $t_{\text {hitung }}$ sebesar 3,324 lebih besar dari nilai $t_{\text {tabel }}$ yaitu 1,653 sehingga hipotesis diterima karena ada pengaruh positif antara dewan komisaris terhadap kinerja keuangan perusahaan.
3. Berdasarkan tabel 1.5 variabel ukuran perusahaan memiliki nilai $t_{\text {hitung }}$ sebesar 1,678, dengan menggunakan uji $t$ diperoleh nilai $\mathrm{t}_{\text {tabel }}$ sebesar 1.653. Hal ini menunjukkan bahwa nilai thitung lebih kecil dari nilai tabel sehingga hipotesis ditolak karena tidak ada pengaruh yang signifikan antara ukuran perusahaan terhadap kinerja keuangan perusahaan.

\section{Hasil Uji Regresi Simultan (Uji F)}

Berdasarkan hasil pengujian statistik $\mathrm{F}$ diperoleh tingkat signifikan sebesar 0,012. Nilai tersebut lebih kecil dari tingkat signifikan yang telah ditetapkan yaitu $\alpha_{0,05}$. Selain itu dapat dilihat nilai $F_{\text {hitung }}$ sebesar 3,753 lebih besar dari nilai $F_{\text {tabel }}$ yaitu sebesar 2,66 (dapat dilihat pada lampiran 14) yang artinya Ho ditolak dan Ha diterima. Jadi dapat disimpulkan bahwa dewan direksi, dewan komisaris, dan ukuran perusahaan secara simultan atau bersama-sama mempunyai pengaruh signifikan terhadap kinerja keuangan perusahaan pada perusahaan manufaktur.

\section{Hasil Uji Koefisien Determinasi $\left(\mathbf{R}^{2}\right)$}

Nilai koefisien determinasi berkisar antara nol sampai dengan satu. Nilai yang mendekati satu berarti variabel-variabel independen memberikan hampir semua informasi yang dibutuhkan untuk memprediksi variabel dependen. Berdasarkan hasil pengujian diperoleh nilai $\mathrm{R}^{2}$ sebesar 0,063 menunjukan bahwa korelasi dewan direksi, dewan komisaris, dan ukuran perusahaan dengan kinerja keuangan perusahaan mempunyai hubungan yang lemah yaitu sebesar 6,3\%. Nilai Adjusted R Square sebesar 0,046 menjelaskan bahwa variabel independen dalam penelitian ini hanya mampu menjelaskan sebesar $4,6 \%$ mengenai variabel dependen yaitu kinerja keuangan perusahaan. Sisanya sebesar $95,4 \%$ dipengaruhi oleh faktor-faktor lain yang tidak diteliti dalam penelitian ini. 


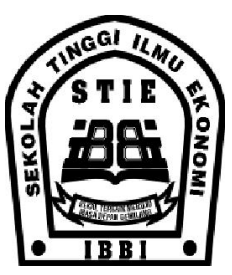

\section{PEMBAHASAN HIPOTESIS}

Berdasarkan hasil penelitian yang telah diuraikan secara statistik, maka untuk memperoleh gambaran yang lebih komprehensif akan dijelaskan lebih rinci lagi sebagai berikut:

1. Hipotesis Pertama $\left(\mathrm{H}_{1}\right)$

Hipotesis pertama menyatakan bahwa ukuran dewan direksi dan ukuran dewan komisaris berpengaruh positif terhadap kinerja keuangan perusahaan. Berdasarkan pengujianpengujian yang dilakukan oleh peneliti, hipotesis pertama ditolak karena tidak ada pengaruh yang signifikan antara dewan direksi terhadap kinerja keuangan perusahaan.

Hasil penelitian ini konsisten dengan penelitian Bukhori (2012) yang dalam penelitiannya menjelaskan bahwa jumlah dewan yang besar menguntungkan perusahaan dari sudut pandang pengelolaan sumber daya. Akan tetapi, semakin besar jumlah dewan direksi juga akan meningkatkan permasalahan dalam hal komunikasi dan koordinasi. Semakin meningkatnya jumlah dewan direksi juga membuat pengawasan yang dilakukan akan semakin sulit, sehingga menimbulkan permasalahan agensi yang muncul dari pemisahan antara manajemen dan control.

Berbeda dengan variabel dewan direksi, pengujian yang dilakukan untuk variabel dewan komisaris menunjukkan adanya pengaruh positif antara dewan komisaris terhadap kinerja keuangan perusahaan sehingga hipotesis diterima. Jadi, semakin banyak jumlah anggota dewan komisaris belum tentu memperlambat pengambilan keputusan dan pengendalian manajemen guna kepentingan kinerja keuangan perusahaan.

Hasil penelitian ini berbeda dengan hasil penelitian Bukhori (2012) yang meyatakan bahwa semakin banyak jumlah anggota dewan komisaris, maka dewan komisaris akan semakin kesulitan dalam menjalan peran. Diantaranya adalah kesulitan dalam mengawasi dan mengendalikan tindakan manajemen, serta kesulitan dalam mengambil keputusan yang berguna bagi perusahaan.

2. Hipotesis Kedua

Hipotesis kedua menyatakan bahwa ukuran perusahaan berpengaruh positif terhadap kinerja keuangan perusahaan. Berdasarkan hasil pengujian yang telah dilakukan, tidak ada pengaruh yang signifikan antara ukuran perusahaan terhadap kinerja keuangan perusahaan sehingga hipotesis ditolak. Hal tersebut menunjukan bahwa ukuran perusahaan yang besar dengan total asset yang besar pula belum tentu membuat kinerja keuangan perusahaan semakin baik, bisa jadi dengan terlalu banyak asset yang dimiliki suatu perusahaan dapat menyebabkan kurangnya pengelolaan aktiva lancarnya.

Hasil penelitian ini konsisten dengan penelitian Bukhori (2012) yang dalam penelitiannya menjelaskan bahwa ukuran perusahaan yang besar belum tentu menghasilkan kinerja keuangan yang lebih baik. Semakin besar aset yang dimiliki perusahaan, semakin kompleks pula masalah agensi yang dihadapi.

\section{KESIMPUAN DAN SARAN}

\section{Kesimpulan}

Berdasarkan hasil pengujian dan pembahasan mengenai pengaruh good corporate governance (yang diproksi dengan ukuran dewan direksi dan ukuran dewan komisaris) dan ukuran perusahan terhadap kinerja keuangan perusahaan manufaktur yang diukur dengan CFROA, adapun hasil penelitian dapat dijelaskan secara ringkas sebagai berikut:

1. Good Corporate Governance yang diproksi dengan dewan direksi secara parsial tidak berpengaruh terhadap kinerja keuangan perusahaan, dan dewan komisaris secara parsial berpengaruh terhadap kinerja keuangan perusahaan manufaktur yang terdaftar di Bursa Efek Indonesia (BEI) periode 2013-2014.

2. Ukuran perusahaan secara parsial tidak berpengaruh terhadap kinerja keuangan perusahaan manufaktur yang terdaftar di Bursa Efek Indonesia (BEI) periode 20132014.

3. Dewan direksi, dewan komisaris, dan ukuran perusahaan secara simultan berpengaruh terhadap kinerja keuangan 


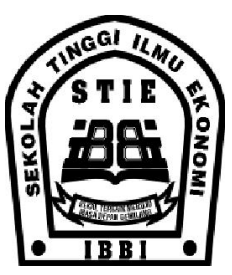

perusahaan manufaktur yang terdaftar di Bursa Efek Indonesia (BEI) periode 20132014.

\section{Keterbatasan Penelitian}

Penelitian ini memiliki beberapa keterbatasan, diantaranya sebagai berikut:

1. Dalam penelitian ini nilai $\mathrm{R}^{2}$ sangat kecil yaitu sebesar $6,3 \%$ dari nilai ketetapan yaitu $100 \%$. Hal ini menunjukkan bahwa kineja keuangan perusahaan dapat dipengaruhi oleh faktor-faktor lain yang tidak diteliti dalam penelitian ini.

2. Penelitian ini hanya menggunakan dua variabel independen dan satu variabel dependen.

\section{Saran}

Berdasarkan beberapa keterbatasan yang ada dalam penelitian ini, sehingga peneliti menyarankan:

1. Peneliti menyarankan kepada peneliti selanjutnya agar menambah atau menggunakan variabel independen dan variabel dependen yang berbeda dengan penelitian ini seperti komisaris independen, komite audit, kepemilikan konstitusional, komposisi aktiva, ROI, ROE dan lain-lain serta menggunakan populasi dan sampel yang berbeda seperti perusahaan di sektor perbankan, consumer goods, pertambangan dan lain sebagainya guna menambah wawasan yang baru.

2. Peneliti menyarankan bagi peneliti selanjutnya, laporan keuangan tahunan yang digunakan sebagai data penelitian sebaiknya menggunakan periode yang lebih panjang agar mampu memberikan keefektifan dari kebijakan yang berhubungan dengan good corporate governace dan ukuran perusahaan terhadap kinerja keuangan perusahaan.

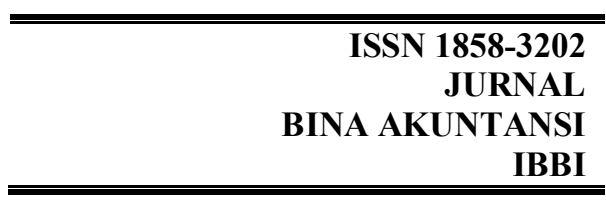

\section{DAFTAR PUSTAKA}

Arifin, H.I., dan Anis Chariri. 2011. Hubungan Antara Mekanisme Good Corporate Governance (Komisaris Independen, Kepemilikan Manajerial, Kepemilikan Asing, Hutang Dan Kualitas Audit) Dengan kinerja Saham. Semarang. Universitas Diponegoro.

Bukhori, I. 2012. Pengaruh Good Corporate Governance dan Ukuran Perusahaan Terhadap Kinerja Perusahaan (Studi empiris pada Perusahaan Manufaktur yang terdaftar di BEI 2010). Semarang. Universitas Diponegoro.

Bukhori, I; dan Raharja. 2012. Pengaruh Good Corporate Governance dan Ukuran Perusahaan Terhadap Kinerja Perusahaan (Studi empiris pada Perusahaan Manufaktur yang terdaftar di BEI 2010). Diponegoro Journal of Accounting.

Cornett, M.M; Alan J. Markus; A. Saunders; and H. Tehranian. 2006. The Impact of Institutional Ownership on Corporate Operating Perfomance. Journal of Banking \& Financial. 31:1771-1794

Darmawati, D; dan Khomsiyah. 2004. Hubungan Corporate Governance Dan Kinerja Perusahaan. Universitas Trisakti. Jakarta.

Forum for Corporate Governance in Indonesia. 2001. Peranan Dewan Komisaris dan Komite Audit dalam Pelaksanaan Corporate Governance. Seri Tata Kelola Perusahaan, Jilid II. Edisi ke-2. Jakarta.

Ghozali, I, 2006. Aplikasi Analisis Multivariate Dengan Program SPSS. Universitas Diponegoro. Semarang. 


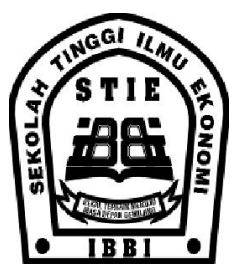

2009. Ekonometrika Teori, Konsep dan Aplikasi Dengan SPSS 17. Universitas Diponegoro. Semarang.

Gozali, N. 2012. Dampak Penerapan PrinsipPrinsip Good Corporate Governance Terhadap Kinerja Perusahan. Jurnal Ilmiah Mahasiswa Akuntansi. Surabaya. Fakultas Bisnis Unika Widya Mandala.

Hardikasari, E. 2011. Pengaruh Penerapan Corporate Governance Terhadap Kinerja Keuangan Pada Industri Perbankan Yang Terdaftar Di Bursa Efek Indonesia (BEI) Tahun 20062008. Universitas Diponegoro. Semarang.

Ikatan Akuntansi Indonesia. 1996. Standar Akuntansi Keuangan. Jakarta. Salemba Empat

Indonesian Institute For Corporate Governance. 2000. Corporate Governance Perception Idex.

Jensen, M.C; and W.H. Meckling. 1976. Theory of The Firm: Managerial Behavior, Agency Cost and Ownership Structure. Journal of Financial Economic. 3:305-360

Keiso, E. Donald., dan Weygandt J Jerry.2008. Akuntansi Intermediate. Jilid Satu, Edisi Kedua belas. Jakarta. Erlangga.

Komite Nasional Kebijakan Governance. 2006. Pedoman Umum Good Corporate Governance Indonesia. http://www.governanceindonesia.or.id/main.html (diakses Juni 2015).

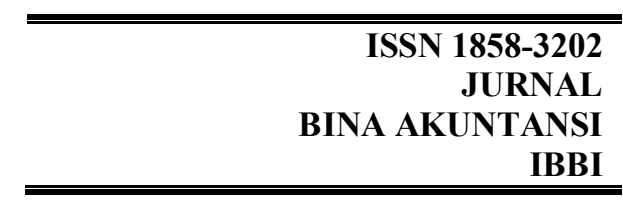

Kusdiyanto; dan Dezy Dwi Kusumaningrum. 2015. Pengaruh Good Corporate Governance Dan Leverage Terhadap Kinerja Keuangan (Studi pada perusahaan Manufaktur yang terdaftar di BEI Tahun 2013-2014). Surakarta. Universitas Muhammadiyah Surakarta.

Pratolo, S. 2007. Good Corporate Governance dan Kinerja BUMN di Indonesia: Aspek Audit Manajemen dan Pengendalian Intern sebagai Variabel Eksogen serta Tinjauannya pada Jenis Perusahaan. Simposium Nasional Akuntansi X. Makassar.

Ross; Stephen; Westerfield, Randolph; dan Jordan, Bradford. 2009. Pengantar Keuangan Perusahaan. Jakarta. Salemba Empat.

Sam'ani. 2008. Pengaruh Good Corporate Governance Dan Leverage Terhadap Kinerja Keuangan Pada Perbankan Yang Terdaftar Di Bursa Efek Indonesia Tahun 2004-2007. Tesis. Semarang. Universitas Diponegoro.

Sugiharto, T. 2007. Kinerja Bank Devisa Dan Bank Non Devisa Dan Faktor-Faktor Yang Mempengaruhinya. E-Journal Ekonomi. Jakarta. Universitas Gunadarma. 10.

Eisenberg, T; Stefan, Sundgren; and Martin, T. Wells. 1998. Larger Board Size And Decreasing Firm Value In Small Firm. Journal of Financial Economic. 48 (1):35-54.

Sriwedari, T. 2009. Mekanisme Good Corporate Governance, Manajemen Laba dan Kinerja Keuangan Perusahaan Manufaktur Di Bursa Efek Indonesia. Tesis. Medan.Universitas Sumatera Utara. 


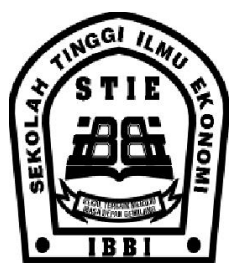

Trinanda; dan Mukodim D. 2010. Effect of Application of Corporate Govenance on the Financial Performance of Banking Sector Companies. Jakarta. Universitas Gunadarma.

Umar, Husein. 2005. Evaluasi Kinerja Perusahaan. Jakarta. Gramedia Pustaka Utama

Wijayanti, S. (2012). Pengaruh Penerapan Corporate Governance Terhadap Kinerja Keuangan Pada Perusahaan Perbankan Yang Terdaftar Di Bursa Efek Indonesia (BEI) Tahun 20092011. Semarang. Universitas Diponegoro.

Yermack, D. 1996. Higher Market Valuation of Companies With A Small Board of Directors. Journal of Financial Economic. 40 (2):185-211

http://www.idx.co.id 